Petrova Iryna,

Doctor in Cultural Studies, professor of EventManagement and Leisure Industry Department, Kyiv

National University of Culture and Arts

ORCID 0000-0002-8146-9200

petrovaiw@gmail.com

\title{
THEORETICAL REFLECTIONS OF THE LEISURE ACTIVITIES IN THE CULTURE OF THE EUROPEAN ENLIGHTENMENT
}

The purpose of the research is to identify the suppositions and factors that form the base of the enlightenment model of the leisure activities. Methodology of the research lies in the usage of a set of systemic, historical and chronological and hermeneutical methods. Scientific novelty of the research is grounded with the origin of the pragmatic approach to the assessment of the leisure activities and leisure practices in the period of Enlightenment. Conclusions. It is proved that the formation of the Enlightenment model of the leisure activities was influenced by such tendencies as the acknowledgement of the leading role of science among other kinds of cognitive activity and the cult of Mind, absolutization of education that formed the belief in the possibility of solving social problems, provided the appropriate conditions for this; deism and secularization of worldview, which led to the denial of religious fanaticism and blind faith in to Church dogmas; social stratification of society. That's why there were dominated such leisure practices that were aimed at the objective cognition of the reality and were based onto the pragmatic ideas.

Keywords: leisure activities, the Enlightenment, absolutization of education, secularization of worldview, deism, secular culture, the European Enlightenment.

Петрова Ірина Владиславівна, доктор культурології, професор, професор кафредри івент-менеджменту та індустрії дозвілля Київського національного університету культури і мистецтв

Теоретичні рефлексії дозвілля в культурі європейського Просвітництва

Метою дослідження $є$ виявлення передумов та чинників, що становлять підґрунтя просвітницької моделі дозвілля. Методологія дослідження полягає у використанні сукупності системного, історико-хронологічного та герменевтичного методів. Наукова новизна здійсненого дослідження зводиться до обґрунтування передумов, що зумовили зародження прагматичного підходу до оцінки дозвілля та дозвіллєвих практик в епоху Просвітництва. Висновки. Доведено, що на формування просвітницької моделі дозвілля вплинули такі тенденції як визнання провідної ролі науки серед інших видів пізнавальної діяльності та культ Розуму; абсолютизація виховання, що формувала віру у можливість вирішення соціальних проблем за умови створення для цього відповідних умов; деїзм та секуляризація світогляду, що спонукали до заперечення релігійного фанатизму й сліпої віри у церковні догмати; соціальна стратифікація суспільства. Тому серед дозвіллєвих практик переважали ті, що були спрямовані на об'єктивне пізнання реальності й мали за основу прагматичні ідеї.

Ключові слова: дозвілля, Просвітництво, абсолютизація виховання, секуляризація світогляду, деїзм, світська культура, європейські просвітителі.

Петрова Ирина Владиславовна, доктор культурологии, профрессор, профрессор кафедры ивент-менеджмента и индустрии досуга Киевского национального университета культуры и искусств

Теоретические рефлексии досуга в культуре европейского Просвещения

Целью исследования является выявление предпосылок и фракторов, составляющих основу просветительской модели досуга. Методология исследования заключается в использовании совокупности системного, историко-хронологического и герменевтического методов. Научная новизна состоит в обосновании предпосылок, обусловивших зарождение прагматического подхода к оценке досуга и досуговых практик в эпоху Просвещения. Выводы. Доказано, что на формирование просветительской модели досуга повлияли такие тенденции как признание ведущей роли науки среди других видов познавательной деятельности и культ Разума; абсолютизация воспитания, которая сформировала веру в возможность решения социальных проблем при условии создания для этого соответствующих условий; деизм и секуляризация мировоззрения, побудившие отрицание религиозного фанатизма и слепой веры в церковные догматы; социальная стратификация общества. Поэтому среди досуговых практик преобладали те, которые были направлены на объективное познание действительности и имели в своей основе прагматичные идеи.

Ключевые слова: досуг, Просвещение, абсолютизация воспитания, секуляризация мировоззрения, деизм, светская культура, европейские просветители.

The topicality of the research. There happened radical changes in the «world picture» in the XVII century, which were predetermined by social and historical processes. The social consciousness was influenced by the processes of secularization, continuous political, military, religious conflicts, with unpredictable consequences at this time, from one point of view and passion for intellectual types of knowledge, perception of human activity as the most important value from the other point of view (F. Bacon, R. Descartes, B. Pascal). The appreciation of the leading role of science among other types of cognitive activities predetermined the attitude to nature as an inexhaustible source of resources to meet the growing human needs. Mind was considered the main source of knowledge basing onto «the introduction of improved application of the mind» (F. Bacon), but not God. The cult of Mind provided for the protection of scientific and technological progress as a means of transforming the world, religious and ethical tolerance, human rights as a citizen, the struggle against class privileges and inhumane relations between people, liberation from religious and moral prejudices. F. Bacon, R. Descartes, J. Locke convinced in their works that it is possible to know the nature and destiny of a man, everything cognate to it (ethics, political institutions, philosophical concepts, religious beliefs) only through the mind and science, regardless of the truths of divine revelation or innate talents.

The analysis of the latest researches and publications. The Epoch of Enlightenment is paid close attention to by the scientists in various scientific spheres: historians, philosophers, cultural scientists, historians in art,

(C) Petrova I., 2019 
teachers. They consider the questions of social, political and pedagogical thoughts (Labutina T. and Il'in D.); peculiarities of the development of the culture (Udkin-Ripun I.), philosophy (Ushkalov L.) and art (Peshikova L.) of this period; the works by outstanding educators (Hlodovskiy R.) etc.

However, there are no answers to the question in the works of domestic scientists «what kind of leisure activities did society have at the period, when the society having got rid of religious traditionalism, formed a new system of values with a predominance of rationalist worldview and freedom of thought in it? ॥

We assume that the aim and ideals of the Enlightenment, namely, human freedom and happiness, peace and tolerance, free-thinking and rejection of religious dogmas, have significantly influenced the understanding of leisure activities, which has been discussed not only in aristocratic salons, but also in pamphlets, plays, intellectual games. Therefore, the aim of our research is to identify the prerequisites and factors that formed the basis of the educational model of leisure activities.

Presentation of the basic material. The absolutization of education, which gave rise to the belief into the possibility of solving social problems, provided that the appropriate conditions for this formed the ethical basis of the philosophy of the XVII century. This was the point of view of the English philosopher J. Locke, and his concept of upbringing of the human person and the role of the social environment in it, including leisure activities as its component, will form the basis of many philosophical, sociological, ideological teachings of European educators. The philosopher considered the state as a product of mutual agreement of people, whose interpersonal behavior is regulated not only by laws, but also by moral criteria and norms.

Arguing that human knowledge is a consequence of internal sensory experience, J. Locke noted its activity aspect in recommendations to meaningful leisure activities: «People can't be in complete inactivity: they have to do something» [4, p. 599]. Being convinced that person's readiness to perceive the world around him is based on the internal experience-reflection, the thinker argued that any harmful passion of a person, any inactivity can be corrected. After all, a person, who does not have any serious hobbies or professional activities does not require entertainment, which is only a means of recreation by changing occupations. And simple inactivity, laziness and apathy are signs of «illness» or «unhealthiness» [4, p. 601]. According to the philosopher, it is possible to achieve the upbringing goal on condition of appropriate organization of leisure activities, because young people can't study, read and talk constantly.

Rejecting games and entertainment that are useless to the body or soul and do not bring pleasure to the person after its ending, J. Locke expressed the opinion about the expediency of filling free time with craft activities, the usefulness of which is determined by the skills that a person acquires in the process of this activity. These crafts include the manufacture of perfumes, varnishing, engraving, some types of work on iron, copper, silver, processing of precious stones or polishing of optical glass. The main thing is that from the activities carried out in his spare time, people had fun. And then «cultivation of the earth, planting of trees, inoculation or other useful occupations can be entertainment not less, than any fashionable sport, the main thing due to which it is able to find pleasure in that, and the habit and knowledge of any craft allow to achieve it» [4, p. 599].

J. Locke persuaded that it's falsely to identify leisure activities with inactivity, as leisure activities may be complicated and tire, as far as hunters' fortune is to rise early, hard riding, and heat, cold and hunger. And, meanwhile, hunting was a habitual entertainment for representatives of the highest social circles. However, the philosopher admitted that the passion for many entertainments that are more tiring than any serious occupation, considered them superfluous and useless: «Only the vanity and swagger of the well-known and wealthy have brought into fashion the useless and dangerous ways of spending free time-pastimes, as they call it, and convince us that learning and doing useful things cannot be a gentleman's entertainment. This was the reason that the cards, dice and drunkenness have gained recognition in the world» [the same, p. 600]. J. Locke considered that many people spend their free time without having other classes that could fill their leisure time.

Regarding the conditions of leisure activities, aimed at «improving your mind», the thinker is convinced that everyone has the ability, sufficient to direct them to the right way and seriously use them, especially in leisure time. No one is so preoccupied with earning a living that he does not find at least a piece of free time to improve his knowledge. J. Locke convinced that experience and social environment play a leading role in the educational process not perceiving opinions about innate abilities and ideas.

The deism is very typical for the culture of the Enlightenment that is the doctrine of free-thinking, which encourages people to deny religious fanaticism, blind faith, defend the freedom of conscience and the emancipation of science and philosophy from the Church's guardianship (Voltaire, Rousseau). The educators criticized the intricate Christian theology, religious fanaticism, focusing on the issues of the afterlife and religious salvation without renouncing religion and faith as such. The God's Law has presented the conception of inalienable rights of the person, the Supreme guarantor of which is the Creator, and their social consequence and manifestation is a social contract that constitutes the Union of people as equal persons. The ideological struggle between religious and anti-religious beliefs resulted in the separation of Church and State (for example, an educational project by G.A. Condorcet).

The enlighteners are convinced that nature in general and human nature in particular, are arranged intelligently and can be learned in a rational way. Rationalism declared knowledge «experimental», «procedural», «verified». The postulation of such equality between science and nature, mind and nature, will eventually become a source of internal contradictions in educational ideology. M. Horkheimer and T. Adorno summarize, criticizing the focus of science in the Enlightenment: «The Enlightenment burned the remains of self-esteem. The identification of the person with the God lies in the sovereignty over existence, in his/her view of the Lord, in 
command... Nature no longer needs to be influenced by assimilation; it needs to be subjugated by labor» [8, p. 18-22]. Enslavement of nature internal and external is recognized as the purpose of life.

The initiator and conductor of scientific and cultural ideas was the intelligentsia as a driving force of society in the Enlightenment. At the same time, success on this way was achieved thanks to another powerful social force that played a significant role in the history of intellectual development of Europe, it was the bourgeoisie, whose hedonistic and optimistic outlook combined personal and public interests, thus determining the socio-cultural dynamics of the era. At the same time with the «atomic» concepts of society and the affirmation of the principle of inalienable human rights and freedoms, it was the bourgeoisie that strengthened personal initiative, personal benefit, personal success and private property as signs of individualism.

The educational idea of progress predicted the achievement of truth about man and the world on the basis of facts. The first systematic presentation was the work by G.A. Condorcet «A Sketch of the Historical Picture of the Progress of the Human Mind» (1795), which justified the prospect of infinite improvement of human nature through scientific knowledge, and it is impossible without leisure time. An important part of the ideology of progressivism is the belief in the appropriate direction of any creative action, as well as knowledge of those areas of life, in which progress is the essence of the reality associated with it. Therefore, the boundless belief in the power and capabilities of the human mind gave rise to the belief that it can help to achieve progress not only knowledge and technical achievements, but also moral values. It was believed that this progress is subject to the General laws of the development of individual abilities, because it is the result of the development of a large number of individuals United in society. However, the outcome depends on what has been achieved in the past and affects what needs to be achieved in the future. In this evolutionary process, the development of human abilities has no limit. The steady ascent of humanity to the heights of reason, justice, goodness and peace may have a different duration of waiting, but this process will never have a reverse direction.

Progressive movement in the early stages of human development G.A. Condorcet characterizes as very slow, which is predefined by the lack of leisure activities, because «...the uncertainty and difficulty of the struggle for existence, the forced alternation of extreme fatigue and absolute rest did not allow a person to have the leisure activity in which, thinking that he/she could enrich his/her mind with a new combinations of ideas» [3, p. 687]. That's why the industry appears only when «greater security, more secure and constant leisure activities allow a person the opportunity to devote himself to reflection or system monitoring in extreme cases» [the same, p. 688]. The presence of permanent leisure activities, which frees a person from work, generates a class of people, whose time is not absorbed by physical labor completely, and their desire is wider than primitive needs. It is the case when a person directs his/her abilities to self-improvement. That is, the progress of science, which ensured the progress of industry, would be impossible without leisure activities and this mutual influence has become a powerful force for the improvement of the mankind.

The importance of education and the role of leisure in the educational process is mentioned in the works by I. Kant («About Pedagogy», 1803). A person can become a Person only in the process of education, which is a great mystery of the improvement of human nature. And the greatest and most difficult task of the mankind is the education. However, parents and officials give too little attention and this prevents the improvement of man. Covering the concept «education» care, discipline, training and the formation of a moral person, I. Kant noted that the educational goal can be achieved not by mastering special knowledge, but also by strengthening the spiritual forces of the pupil. Physical education of the spirit is possible with a combination of free and systematic approaches. "Free education is supposedly a game; systematic, on the contrary, «the real» occupation; the results of free education should be manifested in the child constantly and invariably, and systematic should provide for a certain pressure onto the pupil. Game activities, leisure activities, but employment under the compulsion of the necessity is the work itself. Systematic education should be a work for a child and free one is a game» [1, p. 431]. Therefore, school should teach the child to work, and real leisure activities can only be such after work.

So, there approved to be fundamentally new views on leisure activities in the Epoch of Enlightenment, its impact on the creative possibilities of a man. A strong-willed person appears to be in the center of the educational concept of leisure activities, and is able to make his/her own decisions and "use his/her own mind» I. Kant). Rationalist ideology of this epoch had a very vivid educational context. The subject of spiritual production was the educated elite, which had to convey knowledge to the «uneducated» of superstitious and biased mass. Educators considered it possible to overcome ignorance and social passivity of the ordinary population by increasing its literacy, increasing the time for «useful» leisure activities and assimilation of cultural values.

Analyzing this epoch, J. Real and D. Antiseri noted: «Mind is not so much mastering as conquest. It is neither a Treasury of the spirit nor a repository in which the truth is safely stored.., on the contrary, the mind is the driving force that generates spiritual wealth, leading to the revelation of truth, and it is an embryo and a necessary precondition for any genuine confidence» [7, p. 595].

However, the intellectual elite was separated from the potential consumer of its products (scientific discovery, knowledge, etc.) by its privileged position in society. It is not surprising that the idea of idleness and idleness of simple people was widespread in scientific works of XVII-XVIII centuries, who on the social position were considered far from educational and cultural development through material deprivations and constant employment in the sphere of material production. The attention of the thinkers of the Modern Epoch was attracted by the insurmountable border between the cultural agent and the ignorant masses. 
Analyzing the "educational" project, M. Mamardashvili summed up: «the classical thinker experienced his leisure activity, his social privilege for mental work as a metaphysical privilege, as an unconditional right to think for all others, to be a representative in the sphere of the mind on behalf of those who are deprived of the opportunity to find and cultivate their minds. The exclusion from the system of material production, of anxieties and worries is related to the maintenance of physical existence and was understood by them as freedom from passions, interests, self-interest and their ill-wresting influence on the process of knowing the truth: the classical thinker felt excluded from the socio-forced illusion due to a special, restricted situation of different social groups. $\mathrm{He}$ considered himself an absolute observer, outside any socio-relative «counting systems», and therefore is able to see directly a real state of affairs» [6, p. 57]. This illusion, on the one hand, was the source of the colossal inner strength of classical philosophy and humanism, and on the other, the main reason for their limitations. It provided a powerful energy of ideological asceticism, and at the same time led to a paternalistic way of thinking, to insensitivity, closeness to any ignorant experience.

Scientific novelty. Extrapolation to the sphere of leisure activities such values as diligence, prudence, rationality approved the emergence of a pragmatic approach to the assessment of leisure behavior by the ideologists of Education (D. Jefferson. G.A. Condorcet, J. Locke, J.J. Rousseau, B. Franklin). Moral and rigor concept of leisure activities in the philosophy of Education recognizes valuable for human life and society only those ideas and possibilities of objective knowledge of reality, which are obtained rationally. Therefore, among leisure practices dominated those that were aimed at an objective knowledge of reality and were based on pragmatic ideas (a vivid example is the views of American educators).

Summary. The following trends influenced the formation of the educational model of leisure activities: the recognition of the leading role of science among other types of cognitive activity and the cult of Mind; the absolutization of education, formed a belief in the possibility of solving social problems, provided the creation of appropriate conditions for this; deism and secularization of the worldview, which led to the denial of religious fanaticism and blind faith in Church dogmas; social stratification of society.

In particular, the ideological basis of a person's worldview of the late XVIII-XVIII century was a deistic perception of the world, which rejected religious scholasticism and the fanaticism of the Church, recognized the reason and science and the goal of human activity. Rationalism and pragmatism denied detached, "contemplative" knowledge, defending the human right to freedom of choice and absolutizing moral education. G.A. Condorcet argued that the progress of science, which ensured the progress of industry, would be impossible without leisure activities, and namely this interaction has become a driving force for the betterment of humanity. J. Locke in recommendations as far as meaningful leisure activities noted its active aspect and opportunities to apply the skills acquired in practical life. W. Franklin and T. Jefferson perceived leisure activities as one of the values of life, for which it is advisable to work all my life.

Despite the undeveloped problems raised in the study, in future it seems appropriate to study the impact of educational ideas not only on the theoretical reflection of leisure activities, but also on the cultural and leisure practices.

\section{תimepamypa}

1. Дж. Мысли о том, что читать и изучать джентльмену / Сочинения: в 3 т. Т. 3. М. : Мысль, 1988. С Кант И. О педагогике // Собрание сочинений в 8 томах. Т. 8. М. : Чоро, 1994. С. 399-462.

2. Кант И. Ответ на вопрос: что такое Просвещение? // Собрание сочинений в 8 томах. Т.8. М. : Чоро, 1994. С. 29-37.

3. Кондорсе Ж. А. Эскиз исторической картины прогресса человеческого разума / Антология мировой философии. В 4-х т. Т. 2. Европейская философия от эпохи Возрождения по эпоху Просвещения / [общ. ред., вступ. статья В. В. Соколов]. М. : Мысль, 1970. С. 685-693.

4. Локк Дж. Мысли о воспитании / Сочинения: в 3 т. Т. 3. М. : Мысль, 1988. С. 409-608.

5. Локк. 609-614.

6. Мамардашвили М. К., Соловьев Э. Ю., Швырев В. С. Классика и современность: две эпохи в развитии буржуазной философии // Философия в современном мире. Философия и наука. М. : Наука, 1972. С. 28-94.

7. Реале Дж. Д. Антисери. Западная философия от истоков до наших дней. От романтизма до наших дней / пер. с итал. и ред. С. А. Мальцевой. СПб. : Пневма, 2003. 880 с.

8. Хоркхаймер М., Адорно Т. Диалектика просвещения. Философские фрагменты. М. ; СПб., 1997. 312 с.

\section{References}

1.Kant, I. (1994). O pedagogike. Sobranie sochineniy, vol.8. M. : Choro, 399-462 [in Russian].

2.Kant, I. (1994). Otvet na vopros: chto takoe Prosveshchenie? // Sobranie sochineniy v 8 tomakh. T.8. M. : Choro, 29-37 [in Russian].

3.Kondorse, Zh. A. (1970). Eskiz istoricheskoy kartiny progressa chelovecheskogo razuma. Antologiya mirovoy filosofii. Vol. 2. Yevropeyskaya filosofiya ot epokhi Vozrozhdeniya po epokhu. M. : Mysl, 685-693 [in Russian].

4.Lokk, Dzh (1988). Mysli o vospitanii vol.2. M. : Mysl, 409-608 [in Russian].

5. Lokk, Dzh. (1988). Mysli o tom, chto chitat i izuchat dzhentlmenu / Sochineniya, vol.3. M. : Mysl, 609-614 [in Russian].

6. Mamardashvili, M. K., E. Yu. Solovev, V. S. Shvyrev (1972). Klassika i sovremennost: dve epokhi v razvitii burzhuaznoy filosofii. Filosofiya v sovremennom mire. Filosofiya i nauka. M. : Nauka, 28-94 [in Russian].

7. Reale Dzh. D. Antiseri (2003). Zapadnaya filosofiya ot istokov do nashikh dney. Ot romantizma do nashikh dney. SPb : Pnevma [in Russian].

8. Khorkkhaymer M., Adorno T. (1997). Dialektika prosveshcheniya. Filosofskie fragmenty. M. ; SPb [in Russian]. 